\title{
APOPTOSIS GENE NETWORK REGULATED BY DELTA-TOCOTRIENOL IN K562 CHRONIC MYELOID LEUKAEMIA CELLS
}

\author{
NG KAY LEE*; AMMU KUTTY RADHAKRISHNAN and KANGA RANI SELVADURAY**
}

\begin{abstract}
Palm oil is rich in various health-beneficial phytonutrients. The vitamin $E$ and the carotenoids make up a large portion of these phytonutrients. The tocotrienols are a relatively newer class of vitamin $E$ isoforms that are actively being researched for its various health promoting properties. In this study, the anti-cancer properties of the delta-tocotrienol $(\delta-T 3)$ isoform were investigated on a leukemic cell line. A preliminary cytotoxicity assay was carried out to identify $\delta$-T3's potency in inducing cell death. Following this a real time-based gene array experiment was carried out to distinguish the apoptosis genes regulated by $\delta$-T3 in the K562 leukemic cell line. Results show that treatment with $\delta$-T3 significant regulated the expression of several genes that promote apoptosis such as TP53, TP73, HRK, MCL1, CASP7, CASP8, DAPK1, PYCARD, FASLG and TNFRSF9. These findings suggest that palm $\delta$-T3 can exert anti-cancer activities in chronic myeloid leukemic cells
\end{abstract}

Keywords: tocotrienol, apoptosis, cytotoxicity.

Date received: 12 May 2015; Sent for revision: 28 December 2015; Received in final form: 28 February 2017; Accepted: 26 April 2017.

\section{INTRODUCTION}

The oil palm is aptly known as the 'golden crop' due to its various beneficial uses. Palm oil which is extracted from the fruit of the oil palm contains various phytonutrients, especially vitamin $\mathrm{E}$ and the carotenoids (Bonnie and Choo, 2000). Vitamin E is a naturally-occurring antioxidant, which is made up of two main sub-families, namely tocopherols and tocotrienols (T3). Each sub-family can be further classified in four isoforms: alpha $(\alpha)$, beta $(\beta)$, delta $(\delta)$ and gamma $(\gamma)$ based on their chemical structures. The tocotrienols are relatively more

\section{School of Medicine}

International Medical University,

129, Jalan Jalil Perkasa 19, Bukit Jalil,

57000 Kuala Lumpur, Malaysia.

E-mail: ammu_radhakrishnan@imu.edu.my

** Malaysian Palm Oil Board, 6 Persiaran Institusi,

Bandar Baru Bangi, 43000 Kajang,

Selangor, Malaysia. potent in inhibiting cancer cell growth compared to the tocopherols (Pierpaoli et al., 2010a). Research has shown that tocotrienols possess potent anticancer activity such as anti-metastatic (Liu et al., 2010), inhibition of lipid peroxidation and nitric oxides (Kamat et al., 1997), anti-angiogenic (WengYew et al., 2009), pro-apoptosis (Loganathan et al., 2013) and enhance cell-mediated immune responses (Nesaretnam et al., 2004).

Cancer is a genetic disease, caused by malfunctions in various oncogenes, tumour suppressor genes and stability genes (Vogelstein and Kinzler, 2004). Mutations in oncogenes cause these genes to be constitutively active as opposed to their wild-type counterparts. Therefore, dysfunction of these genes can provide opportunities for carcinogenesis. Due to a cell's inherent protection, it has been argued that cancer cannot be due to a single gene defect and that that cancer occurs due to the accumulation of multiple defects in our genes (Vogelstein and Kinzler, 2004). 
It has been suggested that genes can cause disruptions in various physiological processes such as apoptosis or programmed cell death that can be used to eliminate 'rogue' or cancer cells (Lowe and Lin, 2000). Hence, it is becoming important to identify genes that play a role in allowing cancers to develop and evade the immune system so that we can understand the mechanisms that support or promote oncogenesis. Apoptosis is a crucial process to maintain normal tissue development and function. Previously, the chemotherapeutic drugs used were designed to target accelerated cell growth, based on the premise that tumour cells had a faster growth rate compared to normal cells (Johnstone et al., 2002). Despite that, studies have indicated that most classes of chemotherapeutic drugs used in cancer therapy have the ability to induce apoptosis, including the anti-metabolites (Sarraf et al., 1993), DNA fragmenting (Tounekti et al., 1993) and DNA crosslinking agents (Osawa et al., 2011), intercalating agents (Skladanowski and Konopa, 1993), protein synthesis inhibitors (Story et al., 1993), kinase inhibitors (Jacquel et al., 2003) and many more.

The challenge lies in developing an effective chemotherapeutic agent that induces selective death in tumour cells, but spares the normal healthy cells (Kasibhatla and Tseng, 2003). Therefore, in this study, we attempted to elucidate the anti-cancer properties of the tocotrienol isoform, delta-tocotrienol $(\delta-T 3)$ in an in vitro model. The K562, a cell line isolated from a CML patient was selected as a cell-based model for this study. To our knowledge, there have not been many reports outlining the function of $\delta-\mathrm{T} 3$ in inhibiting leukemic cell growth. The objectives of this study are to: (i) investigate the cytotoxicity of $\delta$-T3 towards K562 cells and (ii) to investigate the apoptotic genes regulated by $\delta$-T3 that lead to K562 cell death.

\section{METHODOLOGY}

\section{Test Compound}

Stock solutions of $10 \mathrm{mg} \mathrm{ml}^{-1}$ palm $\delta$-T3 (kind gift from Davos Life Sciences Ptd Ltd, Singapore) was prepared in dimethyl sulfoxide (Sigma, USA) and stored at $-20^{\circ} \mathrm{C}$.

\section{Cell Culture}

The human chronic myeloid leukemic cells (K562 cells) were maintained in complete culture media [RPMI 1640 media (Gibco, USA) supplemented with $10 \%$ fetal bovine serum (Gibco, USA) and 1\% pen-strep (Gibco, USA)] in a humidified incubator supplied with 5\% carbon dioxide $\left(\mathrm{CO}_{2}\right)$ at $37^{\circ} \mathrm{C}$. Cells were sub-cultured twice weekly. These cells are non-adherent cells.

\section{Cytotoxicity Assay}

Two-fold serial dilutions of the $\delta$-T3 stock solution $\left(30 \mu \mathrm{g} \mathrm{ml}^{-1}\right)$ were performed in 96 wells. The K562 cells were seeded into 96-well plates preloaded with $\delta$-T3 at a density of 10000 cells / well and cultured for 24,48 or $72 \mathrm{hr}$ at $37^{\circ} \mathrm{C}$ in a humidified $\mathrm{CO}_{2}$ incubator. Untreated cells served as control. At the end of each time-point, $20 \mu \mathrm{l}$ of the 3-(4,5-Dimethyl2-thiazolyl)-2,5-diphenyl-2H-tetrazolium bromide (MTT) reagent ( $5 \mathrm{mg} \mathrm{ml}^{-1}$ ) (Sigma, USA) was added into each well and the plate was incubated at $37^{\circ} \mathrm{C}$ in a humidified $\mathrm{CO}_{2}$ incubator for $4 \mathrm{hr}$. After $4 \mathrm{hr}$, the plate containing K562 cells was centrifuged ( $200 \mathrm{~g} \mathrm{x}$ $10 \mathrm{~min}$ ) to pellet the formazan crystals. Following this the supernatant was aspirated and discarded. Then $100 \mu \mathrm{l}$ of DMSO was added to each well to solubilise the formazan crystals that were formed and the absorbance at $570 \mathrm{~nm}$ was read using a microplate reader (Dynex Technologies, USA). Cell viability was calculated using the following formula (Loganathan et al., 2013):

$$
\begin{aligned}
& \text { Percentage cell viability }=\left[\mathrm{Abs}^{*} \text { treated cells } / \mathrm{Abs}^{*}\right. \\
& \text { control cells }] \times 100 \\
& { }^{*} \mathrm{Abs}=\text { Absorbance of cells at } 570 \mathrm{~nm} .
\end{aligned}
$$

\section{RNA Extraction}

The K562 cells were treated with $\delta$-T3 at their 72 hr $\mathrm{IC}_{50}$ dose as obtained from the cytotoxicity assay $\left(8.04 \mu \mathrm{g} \mathrm{ml}^{-1}\right)$ and cultured for $72 \mathrm{hr}$ at $37^{\circ} \mathrm{C}$ in a humidified $\mathrm{CO}_{2}$ incubator. Untreated cells were used as control. Ribonucleic acid (RNA) was extracted from untreated and $\delta$-T3-treated K562 cells using the RNeasy Plus Mini Kit using the manufacturer (QIAGEN, Germany) recommended protocol. The RNA samples were tested for quantity and quality as well as RNA integrity. Only RNA samples with the absorbance (Tecan, USA) at 260:230 nm ratio $>1.7$ as well absorbance at 260:280 nm ratio $>1.8$ were selected for verification of RNA integrity using a bioanalyser (Agilent, USA). For the quantitative Real-time polymerase chain reaction (qPCR) analysis, only RNA samples with RNA integrity number (RIN) values more than 7 were used.

\section{Human Apoptosis Quantitative PCR Array}

The human apoptosis qPCR array (SABiosciences, USA) was run in three biological replicates for $\delta$-T3-treated K562 cells as well as the untreated cells (negative control). Briefly, the RNA samples that passed the criteria set by manufacturer $(260 / 230$ ratio $>1.7 ; 260 / 280$ ratio $>1.8$ and RIN > 7) were reverse transcribed to complementary DNA (cDNA) using the $\mathrm{RT}^{2}$ First Strand Kit (SABioscience, USA). The cDNA and the qPCR components were prepared with the $\mathrm{RT}^{2}$ 
SYBR Green Mastermix (SABiosciences, USA) and mixed with the appropriate volume of ultra-pure water before loading into the $\mathrm{RT}^{2}$ Profiler PCR array's 96-well plate (SABiosciences, USA) as per manufacturer's instructions (SABiosciences, USA). The qPCR was performed in IQ5 Thermal-cycler (Biorad, USA) with the following cycling condition: One cycle of $10 \mathrm{~min}$ at $95^{\circ} \mathrm{C}$ followed by 40 cycles of $15 \mathrm{~s}$ at $95^{\circ} \mathrm{C}$ and $1 \mathrm{~min}$ at $60^{\circ} \mathrm{C}$. Then one cycle was run for $1 \mathrm{~min}$ at $95^{\circ} \mathrm{C}$ followed by another cycle at $55^{\circ} \mathrm{C}$. Finally, 81 cycles were run for $10 \mathrm{~s}$ each at $55^{\circ} \mathrm{C}$. Fold change was calculated using the $\Delta \Delta \mathrm{C}_{\mathrm{T}}$ method. The threshold cycle $\left(C_{T}\right)$ values for all wells were exported into the PCR Array Data was transferred to a data analysis Excel file provided by the manufacturer (SABiosciences, USA) and data analysis was performed using a web-based PCR Array Data Analysis software that can be accessed using the Internet at the following URL: www. SABiosciences.com/pcrarraydataanalysis.php.

\section{Data Analysis}

Data was expressed as mean \pm standard deviation. The statistical test used was the oneway analysis of variance (ANOVA) followed by the Tukey's post hoc test to distinguish differences between groups. Results were accepted as statistically significant when $\mathrm{p}<0.05$.

\section{RESULTS AND DISCUSSION}

\section{Cytotoxicity Assay}

In anti-cancer therapy, anti-cancer agents are employed to induce cancer cell death, preferably via the induction of apoptosis (Fulda and Debatin, 2006). Therefore, it follows that the first step in determining the anti-cancer potential of $\delta$-T3 was to determine if $\delta-\mathrm{T} 3$ was able to induce cell death of K562 cells. The cytotoxicity of $\delta$-T3 towards K562 cells was measured using the MTT assay. The goal of this assay was to observe and measure the cytotoxicity of $\delta$-T3 towards K562 cells. From our results, we observed that $\delta$-T3 caused a dose- and time-dependent reduction in K562 cell viability (Figure 1). The $\mathrm{IC}_{50}$ values for $\delta$-T3-treated $\mathrm{K} 562$ cells were $11.65,9.46$ and $8.04 \mu \mathrm{g} \mathrm{ml}^{-1}$ ) for 24,48 and $72 \mathrm{hr}$ respectively. To the best of our knowledge, $\delta$-T3-induced toxicity was not reported in this cell line in previous studies. However, $\delta$-T3 was proven effective in inducing the cell death of many cancer cell lines in vitro as measured by their $\mathrm{IC}_{50}$ values, including human liver carcinoma HepG2 cells (9.6 $\mu \mathrm{M})$ (Wada et al., 2005); human acute lymphocytic leukaemia cells CEMSS (3.8 $\mu \mathrm{g} \mathrm{ml}^{-1}$ ) (Wong et al., 2012); and several pancreatic cancer cell lines Mia PaCa-2 $(28 \mu \mathrm{M})$, PANC-1 $(35 \mu \mathrm{M})$ and BxPC-3 (35 $\mu \mathrm{M})$ (Hussein and Mo, 2009). Besides cytotoxicity, $\delta$-T3 reportedly inhibited cell proliferation in the human promyelocytic leukemic cells (HL-60) at doses of $5 \mu \mathrm{g} \mathrm{ml}^{-1}$ and $10 \mu \mathrm{g} \mathrm{ml}^{-1}$ (de Mesquita et al., 2011), which further supports the role of $\delta$-T3 as an effective cytotoxic agent.

It was of our interest to characterise the gene expression changes that led to the induction of K562 cell death upon treatment with $\delta$-T3. This was because many cytotoxic chemotherapeutic agents have apoptosis-inducing potential which leads to tumour cell death. Therefore, we selected a quantitative reverse transcription-polymerase chain reaction (qRT-PCR)-based gene array system to identify the gene network regulated by $\delta$-T3 in K562 cells. The human apoptosis PCR array was a commercial kit utilised for this purpose. From the MTT assay results, we observed cell death to be highly induced following $72 \mathrm{hr}$ treatment with $\delta$-T3. Therefore, we treated K562 cells at their $72 \mathrm{hr} \mathrm{IC}$. dose, performed RNA extraction and eventually, real time PCR analysis. From the 84 genes included in the human apoptosis PCR array, $\delta$-T3 up-regulated the expression of 24 genes related to apoptosis (Table 1). Significant gene expression changes are represented in the form of a volcano plot (Figure 2) They were the BCL-2 family (BAD, BCL2L1, BNIP3L, HRK, MCL1), the caspases (CASP7, CASP8, CASP9), the tumour necrosis factor receptor (TNFR) super family (CD40, FAS, TNFRSF10B, TNFRSF1A, TNFRSF9) and the P53 family (TP53, TP73). Several other genes, such as genes from the caspase recruiting domain (CARD) members (APAF1, BIRC3, NOD1, NOL3 and PYCARD), TNF (ligand) superfamily members (CD70 and FASLG), DAPK1 and GADD45A were also up-regulated in K562 cells following $\delta$-T3 treatment. The interactions between the genes regulated by $\delta$-T3 treatment in K562 cells are shown in Figure 3.

The TP53 gene was induced following tocotrienol-rich fraction (TRF) treatment in human colon carcinoma RKO cells (Agarwal et al., 2004) and in SKBR3 breast cancer cells following exposure to $\delta$-T3 (Pierpaoli et al., 2010b). Similarly, we observed an up-regulation following TP53 gene expression in K562 cells (Table 1). The TP53 gene encodes the P53 tumour suppressor protein. The P53 is central to $\delta$-T3-mediated apoptosis in K562 cells as it regulates genes such as BCL2L1 (Lee et al., 2008), CASP8 (Liu et al., 2011), FAS (Muller et al., 1998), GADD45A (Xiao et al., 2000), MCL1 (Pietrzak and PuzianowskaKuznicka, 2008) and TNFRSF10B (Surget et al., 2012), all of which were over-expressed in the K562 cells following treatment with $\delta$-T3. Mutations in the TP53 gene are reported to predispose an individual to various cancers such as breast cancer (Walerych et al., 2012), soft tissue sarcoma (Cordon-Cardo et al., 1994), bone (Kleihues et al., 1997) and brain (Sidransky et al., 1992) cancers, leukaemia (Felix et al., 


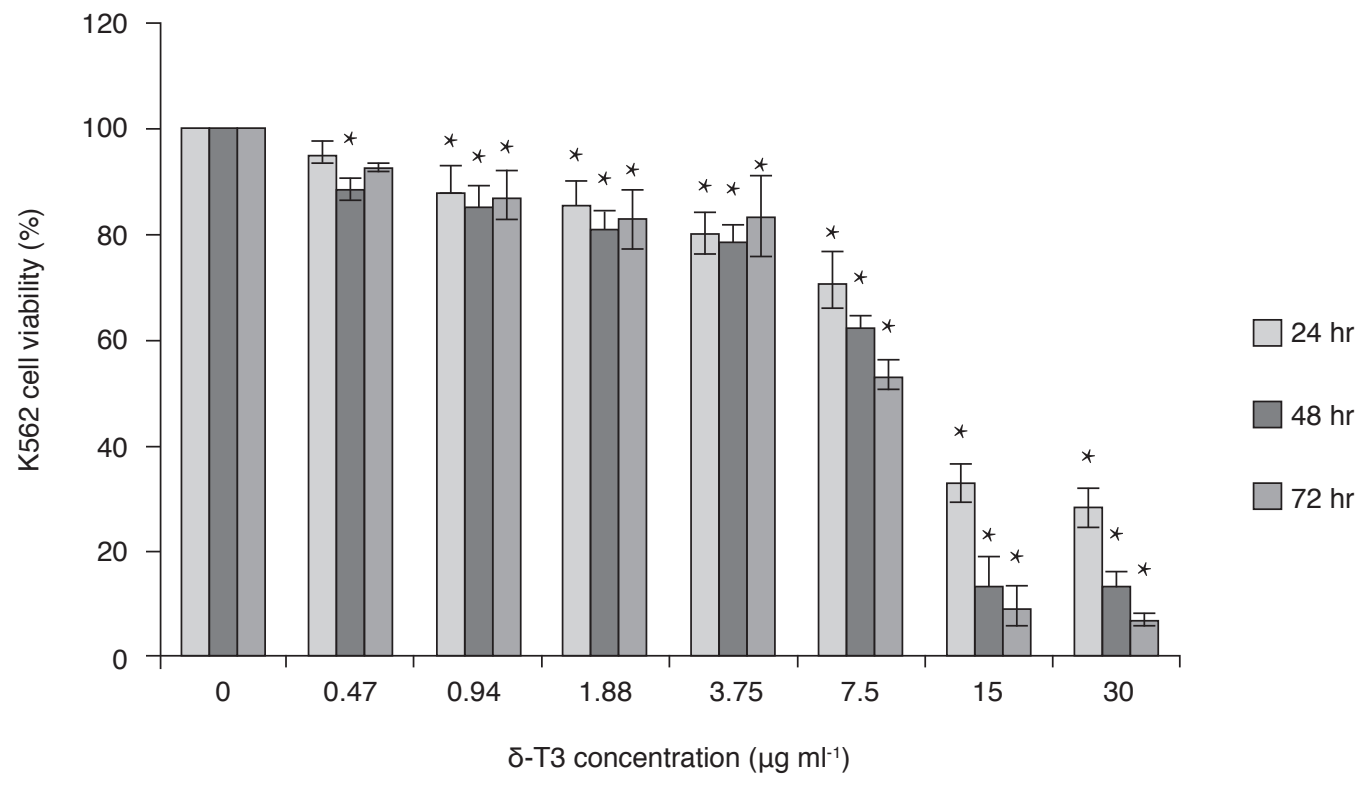

Figure 1. Dose- and time-dependent cytotoxicity of delta-tocotrienol ( $\delta T 3)$ towards K562 cells.

TABLE 1. GENES INVOLVED IN APOPTOSIS THAT WAS DIFFERENTIALLY REGULATED IN K562 CML CELLS TREATED WITH $\delta$-TOCOTRIENOLS

\begin{tabular}{|c|c|c|c|}
\hline Group & Gene symbol & Gene description & Fold ${ }^{*}$ change \\
\hline \multirow{5}{*}{ BCL-2 family } & $B A D$ & BCL2-associated agonist of cell death & 2.4509 \\
\hline & $B C L 2 L 1$ & BCL2-like 1 & 2.0139 \\
\hline & BNIP3L & BCL2/ adenovirus E1B 19kDa interacting protein 3-like & 2.6087 \\
\hline & HRK & Harakiri, BCL2 interacting protein (contains only BH3 domain) & 4.7459 \\
\hline & MCL1 & Myeloid cell leukemia sequence 1 (BCL2-related) & 2.2449 \\
\hline \multirow{5}{*}{ CARD domain } & APAF1 & Apoptotic peptidase activating factor 1 & 2.3349 \\
\hline & BIRC3 & Baculoviral IAP repeat containing 3 & 3.0035 \\
\hline & NOD1 & Nucleotide-binding oligomerisation domain containing 1 & 3.0455 \\
\hline & NOL3 & Nucleolar protein 3 (apoptosis repressor with CARD domain) & 2.5257 \\
\hline & PYCARD & PYD and CARD domain containing & 6.8053 \\
\hline \multirow{3}{*}{ Caspase family } & CASP7 & Caspase 7, apoptosis-related cysteine peptidase & 3.5308 \\
\hline & CASP8 & Caspase 8 , apoptosis-related cysteine peptidase & 2.2038 \\
\hline & CASP9 & Caspase 9, apoptosis-related cysteine peptidase (CARD domain-containing) & 2.4967 \\
\hline GADD family & GADD45A & Growth arrest and DNA-damage-inducible, alpha & 2.4737 \\
\hline \multirow{3}{*}{ P53 family } & TP53 & Tumour protein p53 & 2.5257 \\
\hline & TP73 & Tumour protein $\mathrm{p} 73$ & 3.249 \\
\hline & $C D 40$ & CD40 molecule, TNF receptor superfamily member 5 & 3.539 \\
\hline \multirow{4}{*}{$\begin{array}{l}\text { TNF receptor } \\
\text { superfamily }\end{array}$} & FAS & Fas (TNF receptor superfamily, member 6) & 2.0467 \\
\hline & TNFRSF10B & Tumour necrosis factor receptor superfamily, member $10 \mathrm{~b}$ & 3.2792 \\
\hline & TNFRSF1A & Tumour necrosis factor receptor superfamily, member $1 \mathrm{~A}$ & 2.2243 \\
\hline & TNFRSF9 & Tumour necrosis factor receptor superfamily, member 9 & 8.2059 \\
\hline \multirow{3}{*}{$\begin{array}{l}\text { TNF (ligand) } \\
\text { superfamily }\end{array}$} & CD70 & CD70 molecule & 9.4261 \\
\hline & FASLG & Fas ligand (TNF superfamily, member 6) & 2.8812 \\
\hline & DAPK1 & Death-associated protein kinase 1 & 2.1886 \\
\hline
\end{tabular}

Note: ${ }^{*} \mathrm{P}<0.05$.

1992) and the Li-Fraumeni Syndrome (Malkin et al., 1990). Yonish-Rouach et al. (1991) had reported that restoring TP53 functions in tumour cells can reverse the susceptibility to cancer as the re-introduction of wild type TP53 gene into leukemic cells lacking this gene induced apoptotic cell death (Yonish-Rouach et al., 1991). Another member of the P53 family, the TP73 gene was induced in K562 cells treated with $\delta$-T3 and is commonly induced following DNA damage resulting in apoptosis (Urist et al., 2004). 
Group 2 vs. Control Group

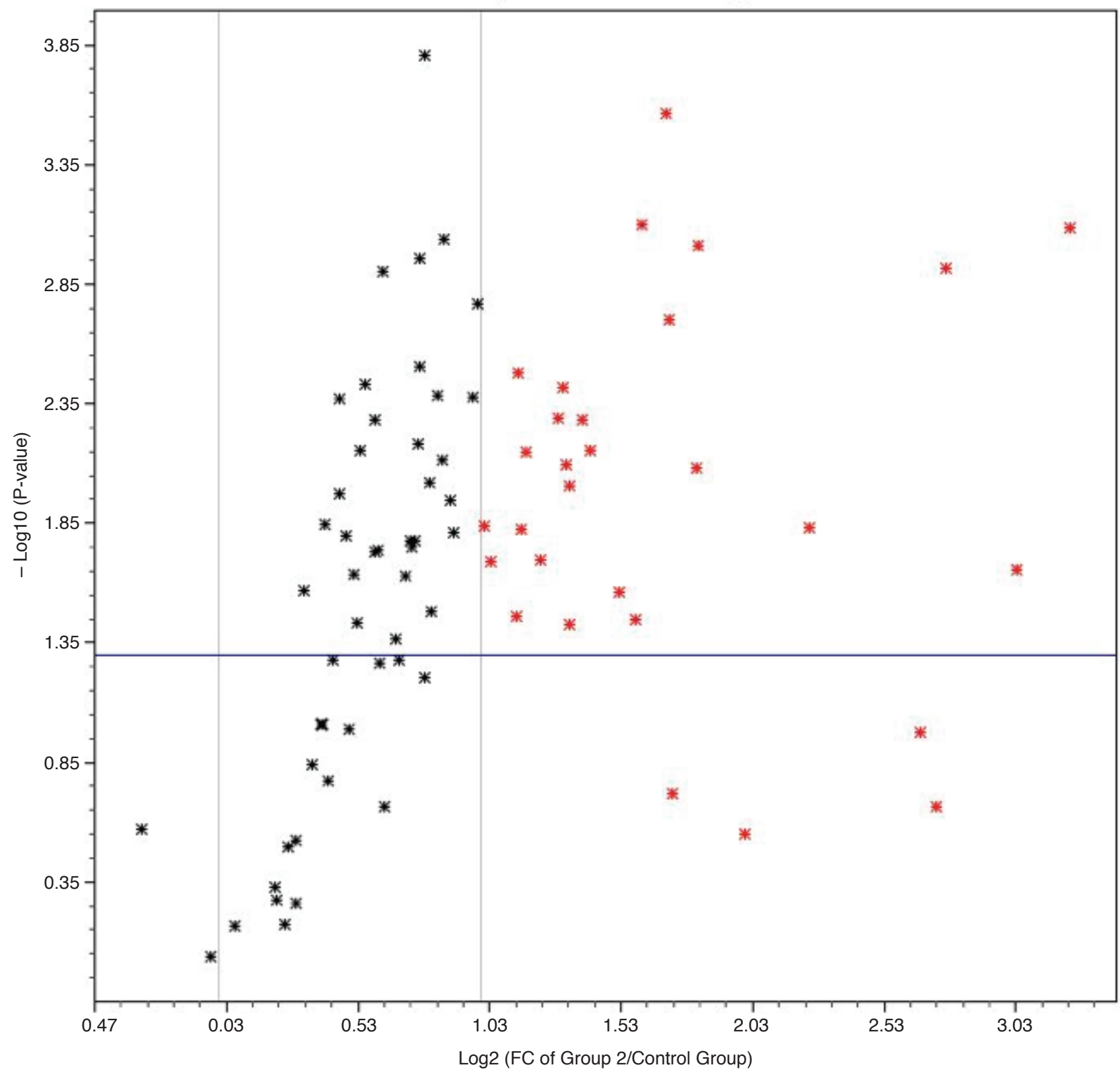

Figure 2. Volcano plot representing significant gene expression changes in K562 cells after treatment with delta-tocotrienol ( $\delta T 3)$. Genes with fold changes of two or more with p-values above 0.05 were considered significantly expressed (upper right quadrant). Real-time polymerase chain reaction $(P C R)$ data is representative of three biological replicates.

In addition to the TP53 gene, $\delta$-T3 treatment also induced over-expression of the TP73 gene in K562 cells treated with $\delta$-T3.

Besides TP53, $\delta$-T3 appears to regulate apoptosis by targeting members of the extrinsic and intrinsic apoptotic pathways by targeting the members of the tumour necrosis factor (TNF) superfamily and TNF ligand superfamily (Table 1). The TNF family and its related receptors play a key role in the extrinsic pathway of apoptosis, especially in its initiation stage (Khosravi-Far and Esposti, 2004). Several death receptor (DR) genes such as FAS, TNFRSF10B and TNFRSF1A genes (Lavrik et al., 2005) were found to be up-regulated in the K562 cells following treatment with $\delta$-T3. The expression of FAS (Wilankar et al., 2011) and TNFRSF10B (Kannappan et al., 2010) were previously reported to be induced by gamma-tocotrienol $(\gamma \mathrm{T} 3)$. The FAS and its ligand, FASLG work hand in hand to bring about apoptotic cell death by the activation of the FAS-associated death domain (FADD) protein and Caspase 8 (CASP8) (Nagata and Golstein, 1995). These molecules form the death-inducing signalling complex (DISC) (Peter and Krammer, 2003), which results in the activation of CASP8, thus triggering the activation of downstream effector caspases (Khosravi-Far and Esposti, 2004). The expression of FAS is induced by the central TP53 protein (Figure 3), 


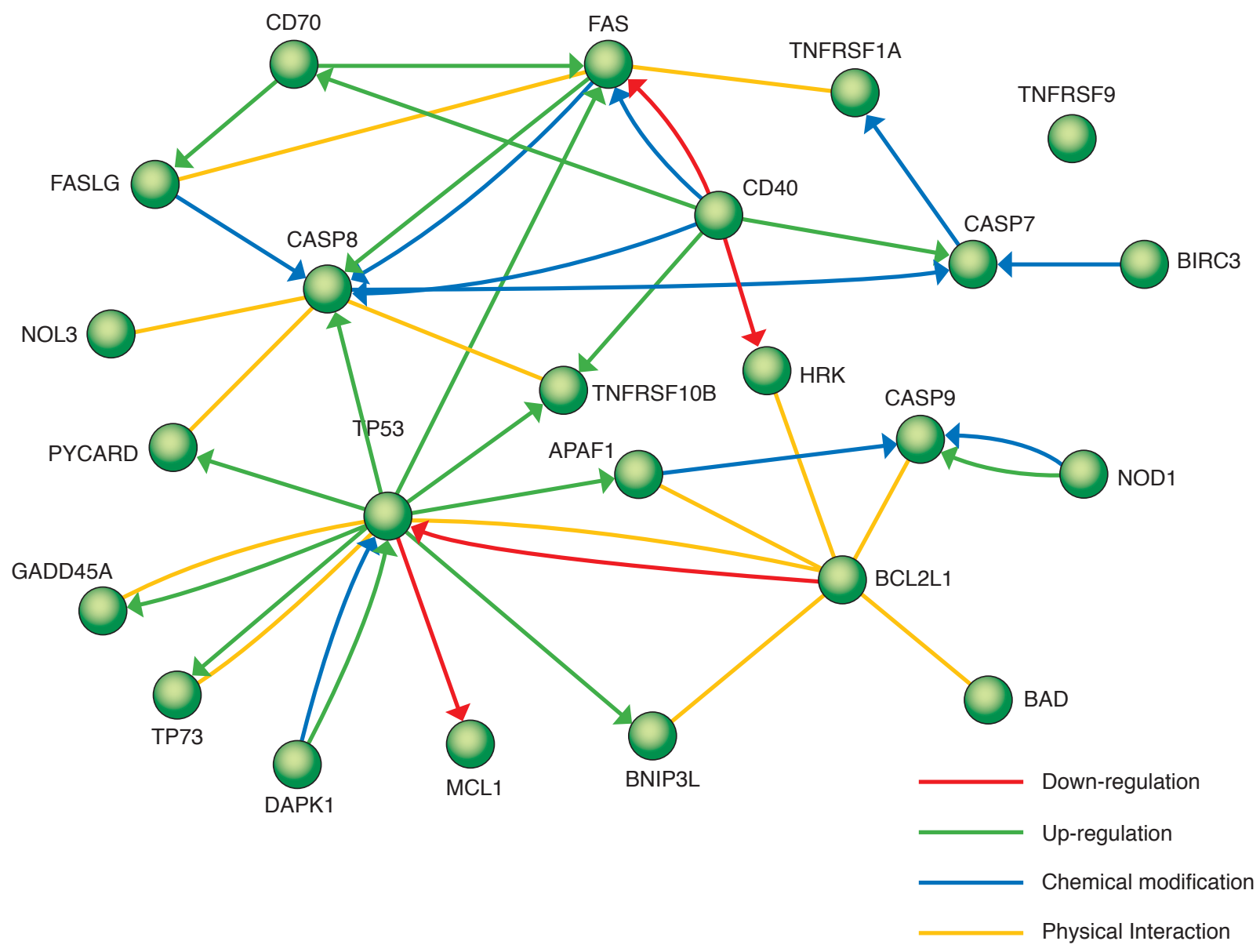

Figure 3. Gene network of apoptotic genes generated using the Gene Network Central Pro software (SABiosciences, USA) for K562 cells treated with delta-tocotrienol ( $\delta$-T3). Only genes expressed with a two-fold increase compared to untreated K562 cells are displayed in this figure.

after cellular events such as DNA damage (Muller et al., 1998). In the leukemic context, FAS expression following chemotherapy has been positively associated with prolonged life span in adult acute myeloid leukaemia patients (Min et al., 2004).

The protein encoded by the TNFRSF10B gene induces apoptotic signalling in the same manner as FAS (Lavrik et al., 2005); i.e. through the formation of the DISC with the recruitment of FADD and subsequent activation of CASP8 (Johnstone et al., 2008). However, TNFRSF1A has a slightly different mode of action that results in either survival (activation of NF- $\mathrm{kB}$ ) or the apoptotic response (death) (Jin et al., 2005). The protein encoded by this gene engages in a transient complex with several proteins, i.e. TNFR-associated death domain (TRADD), RIP1 and TRAF2 (complex I), which triggers the nuclear factor-kappa B (NF- $\kappa \mathrm{B})$ response (Micheau and Tschopp, 2003). Once the death domain (DD) of TRADD is dissociated from TNFRSF1A, it will interact with the DD of the FADD and subsequently with CASP8 (complex II) resulting in apoptosis (Micheau and Tschopp, 2003). The successful formation of complex II and subsequent caspase 8 activation as well as low amounts of FLIP (induced by NF- $\mathrm{B}$ activation) commits the cell to apoptosis, rather than survival (Micheau and Tschopp, 2003).

The intrinsic pathway is mediated by the mitochondria, and the BCL2 family of genes are central to regulating this mode of apoptosis (Thomadaki and Scorilas, 2006). Delta-tocotrienoltreatment of K562 cells induced the expression of several members of this family, namely the $B A D$, $B C L 2 L 1, B N I P 3 L, H R K$ and MCL1 genes. The BCL2 family consist of members dedicated to inducing apoptosis or maintaining survival of cells. The $B A D$, $B N I P 3 L$ and HRK genes belong to the pro-apoptotic BCL-2 family (Reed, 1998). These genes encode the $\mathrm{BH} 3$-only proteins, which is a sequence of amino acids with the motif LXXXGD, of which $X$ represents any amino acid (Youle and Strasser, 2008). These proteins are categorised to be strictly pro-apoptotic proteins (Gross et al., 1999).

Pro-survival genes such as the BCL2L1 $(B C L-X L)$ and MCL1 bear potential oncogenic functions (Adams and Cory, 1998). The prosurvival MCL1 gene induced by $\delta$-T3 treatment has 
important functions in normal cells. For instance, in a murine model, deletion of the MCL1 gene resulted in the failure of embryos to implant in utero (Rinkenberger et al., 2000). The MCL1 gene product is important in the immune system as it is essential to the development and maintenance of B- and T-lymphocytes (Opferman et al., 2003) and haemopoietic cell development (Opferman et al., 2005). This gene remains an attractive target in acute leukaemia treatment as its deletion in AMLafflicted mice cured them of the disease (Glaser et al., 2012). The expression of the MCL1 oncogene can be controlled by the action of TP53 protein as TP53 has been shown to suppress the MCL1 promoter fragment (Pietrzak et al., 2008).

The pro-survival function of BCL2L1 is evidenced by its ability to interact with the proapoptotic BAX that can prevent the permeabilisation of the mitochondria, which then commits the cell to apoptosis (Billen et al., 2008). Previous studies have found that $\delta-T 3$ inhibited expression of BCL2L1 in a murine pancreatic cancer model (Husain et al., 2013). However, in our study, the expression of the BCL2L1 gene was up-regulated following $\delta$-T3 treatment in the K562 CML cells. It has been reported that apoptosis blocked by BCL2L1 can be restored following expression of the $\mathrm{BAD}$ gene as the $B A D$ protein can selectively dimerise with the $B C L 2 L 1$ protein to release the pro-apoptotic BAX (Yang et al., 1995). In this study, we found that $\delta$-T3 treatment induced expression of $B A D$ gene, which may explain why $\delta$-T3 treatment induced apoptosis in the K562 cells despite the up-regulation of the BCL2L1 gene.

The apoptosis process, whether via the intrinsic or extrinsic pathway, converges with the activation of the Ccaspases (Fulda and Debatin, 2006). Caspases are therefore known as the 'executioners of apoptosis' (Hengartner, 2000). Here, we show that $\delta$-T3 treatment can activate a number of genes that code for various types of caspases (caspase 7, 8 and 9) in the K562 CML cells (Table 1). Caspase 8 and 9 are initiator caspases while caspase 7 belongs to the group of effector caspases ( $\mathrm{Li}$ and Yuan, 2008). In literature, it was reported that there are three main effector caspases, CASP3, CASP6 and CASP7 (Li and Yuan, 2008). Briefly, in the intrinsic apoptosis pathway, the release of cytochrome-C from the mitochondria facilitates the formation of apoptosome, which consists of APAF-1 and CASP9; thus, activating the effector caspases (Brentnall et al., 2013). The CASP8 is important in the extrinsic apoptotic pathway mediated by death receptors from the TNF receptor superfamily (TNFSF). Once CASP8 is activated by the formation of DISC, it will continue to activate the effector caspases triggering the caspase cascade (Lavrik et al., 2005). Deltatocotrienol has been reported to activate CASP3 in human melanoma cells (Fernandes et al., 2010) and
CASP3 and CASP8 in pancreatic cancer cells (Husain et al., 2011). However, we observed that only the CASP7 gene is up-regulated in K562 cells exposed to $\delta$-T3 treatment (Table 1). Mice lacking CASP7 were reported to exhibit mild resistance to apoptosis (Lakhani et al., 2006). In addition, CASP7 deficient mice when combined with CASP3 deficiency, were reported to die at birth (Lakhani et al., 2006). These observations provide some concrete evidence on the combined physiological functions of CASP7 and CASP3 in vivo. Furthermore, CASP7 is an effective poly(adenosine diphosphate-ribose) polymerase (PARP) cleaver (Boucher et al., 2012) and PARP cleavage is one of the hallmark features of apoptosis (Soldani and Scovassi, 2002).

\section{CONCLUSION}

Delta-tocotrienol induced expression of many proapoptotic genes (BAD, BNIP3L, HRK, APAF1, NOD1, PYCARD, CASP7, CASP8, CASP9, GADD45A, TP53, TP73, CD40, FAS, TNFRSF10B, TNFRSF1A, TNFRSF9, CD70, FASLG and DAPK1) compared to pro-survival genes (BCL2L1, BIRC3, MCL1 and NOL3). We propose that due to the high ratio of proapoptosis genes compared to pro-survival genes induced in K562 cells, $\delta$-T3 played a regulatory role in inducing cell suicide in K562 cells. Furthermore, $\delta$-T3 induced expression of many genes that code for proteins involved in the extrinsic apoptosis pathway (FAS, FASLG, CASP8, TNFRSF1A and TNFRSF10B) [reviewed in Lavrik et al. (2005) and Elmore, 2007)] as well as the intrinsic apoptotic pathway (APAF-1, CASP9, BCL2L1 and BAD) [reviewed in (Elmore, 2007)]. These findings from the current study suggest that palm $\delta-\mathrm{T} 3$ can exert anticancer activities in chronic myeloid leukemic cells. There is a need to do further studies in animal models to substantiate these findings from the present study.

\section{ACKNOWLEDGEMENT}

The authors would like to thank MPOB for providing a grant to carry out this study as well as Davos Life Science Pte Ltd, Singapore for the kind gift of the delta-tocotrienol isoform.

\section{REFERENCES}

ADAMS, J M and CORY, S (1998). The Bcl-2 protein family: arbiters of cell survival. Science, 281 (5381): 1322-1326.

AGARWAL, M K; AGARWAL, M L; ATHAR, M and GUPTA, S (2004). Tocotrienol-rich fraction of palm oil activates $\mathrm{p} 53$, modulates $\mathrm{Bax} / \mathrm{Bcl} 2$ ratio 
and induces apoptosis independent of cell cycle association. Cell Cycle (Georgetown, Tex.)., 3 (2): 205211.

BILLEN, L P; KOKOSKI, C L; LOVELL, J F; LEBER, $\mathrm{B}$ and ANDREWS, D W (2008). Bcl-XL inhibits membrane permeabilization by competing with Bax. PLoS Biology, 6 (6): e147.

BONNIE, T Y P and CHOO, Y M (2000). Valuable minor constituents of commercial red palm olein: carotenoids, vitamin E, ubiquinones and sterols. J. Oil Palm Res. Vol. 12 (1): 14-24.

BOUCHER, D; BLAIS, V and DENAULT, J-B (2012). Caspase-7 uses an exosite to promote poly(ADP ribose) polymerase 1 proteolysis. Proc. of the National Academy of Sciences of the USA, 109 (15): 5669-5074.

BRENTNALL, M; RODRIGUEZ-MENOCAL, L; DE GUEVARA, R L; CEPERO, E and BOISE, L H (2013). Caspase-9, caspase- 3 and caspase-7 have distinct roles during intrinsic apoptosis. BMC Cell Biology, 14 (1): 32.

CORDON-CARDO, C; LATRES, E; DROBNJAK, M; OLIVA, M R; POLLACK, D; WOODRUFF, J M; MARECHAL, V; CHEN, J; BRENNAN, M F and LEVINE, A J (1994). Molecular abnormalities of mdm2 and p53 genes in adult soft tissue sarcomas. Cancer Res., 54 (3): 794-799.

DE MESQUITA, M L; ARAÚJO, R M; BEZERRA, D P; FILHO, R B; DE PAULA, J E; SILVEIRA, E R; PESSOA, C; DE MORAES, M O; COSTA LOTUFO, L V and ESPINDOLA, L S (2011). Cytotoxicity of $\delta$-tocotrienols from Kielmeyera coriacea against cancer cell lines. Bioorganic \& Medicinal Chemistry, 19 (1): 630 .

ELMORE, S (2007). Apoptosis: a review of programmed cell death. Toxicologic Pathology, 35 (4): 495-516.

FELIX, C A; NAU, M M; TAKAHASHI, T; MITSUDOMI, T; CHIBA, I; POPLACK, D G; REAMAN, G H; COLE, D E; LETTERIO, J J and WHANG-PENG, J (1992). Hereditary and acquired p53 gene mutations in childhood acute lymphoblastic leukemia. The J. Clinical Investigation, 89 (2): 640-647.

FERNANDES, N; GUNTIPALLI, P K and MO, H (2010). d-\{delta\}-Tocotrienol-mediated cell cycle arrest and apoptosis in human melanoma cells. Anticancer Res., 30 (12): 4937-4944.

FULDA, S and DEBATIN, K-M (2006). Extrinsic versus intrinsic apoptosis pathways in anticancer chemotherapy. Oncogene, 25 (34): 4798-811.
GLASER, S P; LEE, E F; TROUNSON, E; BOUILLET, P; WEI, A; FAIRLIE, W D; IZON, D J; ZUBER, J; RAPPAPORT, A R; HEROLD, M J; ALEXANDER, W S; LOWE, S W; ROBB, L and STRASSER, A (2012). Anti-apoptotic Mcl-1 is essential for the development and sustained growth of acute myeloid leukemia. Genes \& Development, 26 (2): 120-125.

GROSS, A; MCDONNELL, J M and KORSMEYER, $S$ J (1999). BCL-2 family members and the mitochondria in apoptosis. Genes $\mathcal{E}$ Development, 13 (15): 1899-1911.

HENGARTNER, M O (2000). The biochemistry of apoptosis. Nature, 407 (6805): 770-776.

HUSAIN, K; CENTENO, B A; CHEN, D-T; FULP, W J; PEREZ, M; ZHANG LEE, G; LUETTEKE, N; HINGORANI, S R; SEBTI, S M and MALAFA, M P (2013). Prolonged survival and delayed progression of pancreatic intraepithelial neoplasia in LSL-KrasG12D/+;Pdx-1-Cre mice by vitamin E d-tocotrienol. Carcinogenesis, 34 (4): 858-863.

HUSAIN, K; FRANCOIS, R A; YAMAUCHI, T; PEREZ, M; SEBTI, S M and MALAFA, M P (2011). Vitamin E $\delta$-tocotrienol augments the antitumor activity of gemcitabine and suppresses constitutive NF- $\kappa \mathrm{B}$ activation in pancreatic cancer. Molecular Cancer Therapeutics, 10 (12): 2363-2372.

HUSSEIN, D and MO, H (2009). d- $\delta$-Tocotrienolmediated suppression of the proliferation of human PANC-1, MIA PaCa-2, and BxPC-3 pancreatic carcinoma cells. Pancreas, 38 (4): e124-136.

JACQUEL, A; HERRANT, M; LEGROS, L; BELHACENE, N; LUCIANO, F; PAGES, G; HOFMAN, P and AUBERGER, P (2003). Imatinib induces mitochondria-dependent apoptosis of the Bcr-Abl-positive K562 cell line and its differentiation toward the erythroid lineage. FASEB Journal: Official Publication of the Federation of American Societies for Experimental Biology, 17 (14): 2160-2162.

JIN, Z and EL-DEIRY, W S (2005). Overview of cell death signaling pathways. Cancer Biology \& Therapy, 4 (2): 139-163.

JOHNSTONE, R W; FREW, A J and SMYTH, M J (2008). The TRAIL apoptotic pathway in cancer onset, progression and therapy. Nature Reviews Cancer, 8 (10): 782-798.

JOHNSTONE, R W; RUEFLI, A A and LOWE, S W (2002). Apoptosis: a link between cancer genetics and chemotherapy. Cell, 108 (2): 153-164.

KAMAT, J P; SARMA, H D; DEVASAGAYAM, T P A; NESARETNAM, K and BASIRON, Y (1997). 
Tocotrienols from palm oil as effective inhibitors of protein oxidation and lipid peroxidation in rat liver microsomes. Molecular and Cellular Biochemistry, 170 (1-2): 131-138.

KANNAPPAN, R; RAVINDRAN, J; PRASAD, S; SUNG, B; YADAV, V R; REUTER, S; CHATURVEDI, M $\mathrm{M}$ and AGGARWAL, B B (2010). Gammatocotrienol promotes TRAIL-induced apoptosis through reactive oxygen species/extracellular signal-regulated kinase/ p53-mediated upregulation of death receptors. Molecular Cancer Therapeutics, 9 (8): 2196-2207.

KASIBHATLA, S and TSENG, B (2003). Why target apoptosis in cancer treatment? Molecular Cancer Therapeutics, 2 (6): 573-580.

KHOSRAVI-FAR, R and ESPOSTI, M D (2004). Death receptor signals to mitochondria. Cancer Biology $\mathcal{E}$ Therapy, 3 (11): 1051-1071.

KLEIHUES, P; SCHÄUBLE, B; ZUR HAUSEN, A; ESTÈVE, J and OHGAKI, H (1997). Tumors associated with p53 germline mutations: a synopsis of 91 families. The American J. Pathology, 150 (1): 1-13.

LAKHANI, S A; MASUD, A; KUIDA, K; PORTER, G A; BOOTH, C J; MEHAL, W Z; INAYAT, I and FLAVELL, R A (2006). Caspases 3 and 7: key mediators of mitochondrial events of apoptosis. Science, 311 (5762): 847-851.

LAVRIK, I; GOLKS, A and KRAMMER, P H (2005). Death receptor signaling. J. Cell Science, 118 (Pt 2): 265-267.

LEE, T L; YEH, J; FRIEDMAN, J; YAN, B; YANG, X; YEH, N T; VAN WAES, C and CHEN, Z (2008). A signal network involving coactivated NF-kappaB and STAT3 and altered p53 modulates BAX/BCL$\mathrm{XL}$ expression and promotes cell survival of head and neck squamous cell carcinomas. International J. Cancer, 122 (9): 1987-1998.

LI, J and YUAN, J (2008). Caspases in apoptosis and beyond. Oncogene, 27 (48): 6194-6206.

LIU, H-K; WANG, Q; LI, Y; SUN, W-G; LIU, J-R; YANG, Y-M; XU, W-L; SUN, X-R and CHEN, B-Q (2010). Inhibitory effects of gamma-tocotrienol on invasion and metastasis of human gastric adenocarcinoma SGC-7901 cells. The J. Nutritional Biochemistry, 21 (3): 206-213.

LIU, J; UEMATSU, H; TSUCHIDA, N and IKEDA, M-A (2011). Essential role of caspase- 8 in p53/p73dependent apoptosis induced by etoposide in head and neck carcinoma cells. Molecular Cancer, 10 (1): 95.

LOGANATHAN, R; SELVADURAY, $\mathrm{K} \quad \mathrm{R}$; NESARETNAM, $\mathrm{K}$ and RADHAKRISHNAN, A K (2013). Tocotrienols promote apoptosis in human breast cancer cells by inducing poly(ADP-ribose) polymerase cleavage and inhibiting nuclear factor kappa-B activity. Cell Proliferation, 46 (2): 203-213.

LOWE, S W and LIN, A W (2000). Apoptosis in cancer. Carcinogenesis, 21 (3): 485-495.

MALKIN, D; LI, F P; STRONG, L C; FRAUMENI, J F; NELSON, C E; KIM, D H; KASSEL, J; GRYKA, M A; BISCHOFF, F Z and TAINSKY, M A (1990). Germ line p53 mutations in a familial syndrome of breast cancer, sarcomas, and other neoplasms. Science, 250 (4985): 1233-1238.

MICHEAU, O and TSCHOPP, J (2003). Induction of TNF Receptor I-mediated apoptosis via two sequential signaling complexes. Cell, 114 (2): 181190.

MIN, Y J; LEE, J-H; CHOI, S-J; CHI, H-S; LEE, J-S; KIM, W-K and LEE, K-H (2004). Prognostic significance of Fas (CD95) and TRAIL receptors (DR4/DR5) expression in acute myelogenous leukemia. Leukemia Research, 28 (4): 359-365.

MULLER, M; WILDER, S; BANNASCH, D; ISRAELI, D; LEHLBACH, K; LI-WEBER, M; FRIEDMAN, S L; GALLE, P R; STREMMEL, W; OREN, $M$ and KRAMMER, P H (1998). p53 Activates the CD95 (APO-1/Fas). Gene in response to DNA damage by anticancer drugs. J. Experimental Medicine, 188 (11): 2033-2045.

NAGATA, S and GOLSTEIN, P (1995). The Fas death factor. Science, 267 (5203): 1449-1456.

NESARETNAM, K; AMBRA, R; SELVADURAY, K R; RADHAKRISHNAN, A; REIMANN, K; RAZAK, G; and VIRGILI, F; 2004. Tocotrienol-rich fraction from palm oil affects gene expression in tumors resulting from MCF-7 cell inoculation in athymic mice. Lipids, 39 (5): 459-467.

OPFERMAN, J T; IWASAKI, H; ONG, C C; SUH, $\mathrm{H}$; MIZUNO, S; AKASHI, K and KORSMEYER, S J (2005). Obligate role of anti-apoptotic MCL-1 in the survival of hematopoietic stem cells. Science, 307 (5712): 1101-1104.

OPFERMAN, J T; LETAI, A; BEARD, C; SORCINELLI, M D; ONG, C C and KORSMEYER, S J (2003). Development and maintenance of B and T lymphocytes requires antiapoptotic MCL-1. Nature, 426 (6967): 671-676. 
OSAWA, T; DAVIES, D and HARTLEY, J A (2011).

Mechanism of cell death resulting from DNA interstrand cross-linking in mammalian cells. Cell Death $\mathcal{E}$ Disease, 2: e187.

PETER, M E and KRAMMER, P H (2003). The CD95(APO-1/Fas) DISC and beyond. Cell Death and Differentiation, 10 (1): 26-35.

PIERPAOLI, E; VIOLA, V; PILOLLI, F; PIRODDI, M; GALLI, F and PROVINCIALI, M (2010a). Gamma- and delta-tocotrienols exert a more potent anticancer effect than alpha-tocopheryl succinate on breast cancer cell lines irrespective of HER-2/ neu expression. Life Sciences, 86 (17-18): 668-675.

PIERPAOLI, E; VIOLA, V; PILOLLI, F; PIRODDI, M; GALLI, F and PROVINCIALI, M (2010b). Gamma- and delta-tocotrienols exert a more potent anticancer effect than alpha-tocopheryl succinate on breast cancer cell lines irrespective of HER-2/neu expression. Life Sciences, 86 (17-18): 668-675.

PIETRZAK, M and PUZIANOWSKA-KUZNICKA, $M$ (2008). p53-dependent repression of the human MCL-1 gene encoding an anti-apoptotic member of the BCL-2 family: the role of Sp1 and of basic transcription factor binding sites in the MCL-1 promoter. Biological Chemistry, 389 (4): 383-393.

REED, J C (1998). Bcl-2 family proteins. Oncogene, 17 (25): 3225-3236.

RINKENBERGER, J L; HORNING, S; KLOCKE, B; ROTH, K and KORSMEYER, S J (2000). Mcl-1 deficiency results in peri-implantation embryonic lethality. Genes \& Development, 14 (1): 23-27.

SARRAF, C E; ANSARI, T W; CONWAY, P; NOTAY, M; HILL, S and ALISON, M R (1993). Bromodeoxyuridine-labelled apoptosis after treatment with antimetabolites in two murine tumours and in small intestinal crypts. British J. Cancer, 68 (4): 678-680.

SIDRANSKY, D; MIKKELSEN, $\mathrm{T}$; SCHWECHHEIMER, K; ROSENBLUM, M L; CAVANEE, W and VOGELSTEIN, B (1992). Clonal expansion of p53 mutant cells is associated with brain tumour progression. Nature, 355 (6363): 846847.

SKLADANOWSKI, A and KONOPA, J (1993). Adriamycin and daunomycin induce programmed cell death (apoptosis) in tumour cells. Biochemical Pharmacology, 46 (3): 375-382.

SOLDANI, C and SCOVASSI, A I (2002). Poly(ADPribose) polymerase-1 cleavage during apoptosis: an update. Apoptosis, 7 (4): 321-328.
STORY, M D; VOEHRINGER, D W; STEPHENS, L C and MEYN, R E (1993). L-asparaginase kills lymphoma cells by apoptosis. Cancer Chemotherapy and Pharmacology, 32 (2): 129-133.

SURGET, S; CHIRON, D; GOMEZ-BOUGIE, P; DESCAMPS, G; MÉNORET, E; BATAILLE, R; MOREAU, P; LE GOUILL, S; AMIOT, $M$ and PELLAT-DECEUNYNCK, C (2012). Cell death via DR5, but not DR4, is regulated by p53 in myeloma cells. Cancer Research, 72 (17): 4562-4573.

THOMADAKI, H and SCORILAS, A (2006). BCL2 family of apoptosis-related genes: functions and clinical implications in cancer. Critical Reviews in Clinical Laboratory Sciences, 43 (1): 1-67.

TOUNEKTI, O; PRON, G; BELEHRADEK, J and MIR, L M (1993). Bleomycin, an apoptosis-mimetic drug that induces two types of cell death depending on the number of molecules internalized. Cancer Research, 53 (22): 5462-5469.

URIST, M; TANAKA, T; POYUROVSKY, M V and PRIVES, C (2004). p73 induction after DNA damage is regulated by checkpoint kinases Chk1 and Chk2. Genes \& Development, 18 (24): 3041-3054.

VOGELSTEIN, B and KINZLER, K W (2004). Cancer genes and the pathways they control. Nature Medicine, 10 (8): 789-799.

WADA, S; SATOMI, Y; MURAKOSHI, M; NOGUCHI, N; YOSHIKAWA, T and NISHINO, H (2005). Tumor suppressive effects of tocotrienol in vivo and in vitro. Cancer Letters, 229 (2): 181-191.

WALERYCH, D; NAPOLI, M; COLLAVIN, L and DEL SAL, G (2012). The rebel angel: mutant p53 as the driving oncogene in breast cancer. Carcinogenesis, 33 (11): 2007-2017.

WENG-YEW, W; SELVADURAY, K R; MING, C H and NESARETNAM, K (2009). Suppression of tumor growth by palm tocotrienols via the attenuation of angiogenesis. Nutrition and Cancer, 61 (3): 367-373.

WILANKAR, C; KHAN, N M; CHECKER, R; SHARMA, D; PATWARDHAN, R; GOTA, V; SANDUR, S K and DEVASAGAYAM, T P A (2011). $\gamma$-Tocotrienol induces apoptosis in human $\mathrm{T}$ cell lymphoma through activation of both intrinsic and extrinsic pathways. Current Pharmaceutical Design, 17 (21): 2176-2189.

WONG, RSY; RADHAKRISHNAN, A K; IBRAHIM, TAT and CHEONG, S-K (2012). $\delta$ - and $\gamma$-Tocotrienols induce classical ultrastructural apoptotic changes in human T lymphoblastic leukemic cells. Microscopy 
and Microanalysis: The Official J. Microscopy Society of America, Microbeam Analysis Society, Microscopical Society of Canada, 18 (3): 462-469.

XIAO, G; CHICAS, A; OLIVIER, M; TAYA, Y; TYAGI, S; KRAMER, F R and BARGONETTI, J (2000). A DNA damage signal is required for p53 to activate gadd45. Cancer Res., 60 (6): 1711-1719.

YANG, E; ZHA, J; JOCKEL, J; BOISE, L H; THOMPSON, C B and KORSMEYER, S J (1995). $\mathrm{Bad}$, a heterodimeric partner for Bcl-xL and Bcl-2, displaces bax and promotes cell death. Cell, 80 (2): 285-291.

YONISH-ROUACH, E; RESNITZKY, D; LOTEM, J; SACHS, L; KIMCHI, A and OREN, M (1991). Wildtype p53 induces apoptosis of myeloid leukaemic cells that is inhibited by interleukin-6. Nature, 352 (6333): 345-347.

YOULE, R J and STRASSER, A (2008). The BCL-2 protein family: opposing activities that mediate cell death. Molecular Cell Biology, 9 (1): 47-59. 